\title{
PERLINDUNGAN HUKUM KORBAN TINDAK PIDANA PENCURIAN RINGAN PADA PROSES DIVERSI TINGKAT PENYIDIKAN
}

\author{
Arfan Kaimuddin \\ PT. Semen Indogreen Sentosa \\ Blok D No. 7, Rukan Darmo Square, J1. Raya Darmo, Tegalsari, Surabaya \\ Email: apan_san@yahoo.co.id
}

\begin{abstract}
Absrtact
This research published as journal is written and motivated by three issues. First is the juridical problems that can be observed from the inconsistency of the Act Number 11 of 2012 on the SPPA from article 1, paragraph (6) of the restorative justice to Article 9 paragraph (2). It has distorted the concept of restorative justice for victims of crime minor theft. The Second is the theoretical issues, that is the right of victims to be protected, but in practice these rights are neglected. the Third issue is the sociological problems that can be observed where the criminal acts of theft committed by a child can interfere with the comfort and safety of the community. This research's objective is to find a basic philosophical formation of Article 9, paragraph (2) of Act No. 11/2012 on SPPA. To describe how should the diversion of the victims of wage theft with losses under local minimum wage was implemented. This journal is written using normative legal research methods. Basic formation of Article 9 (2) Article 9 paragraph (2) of Law No. 11/2012 on SPPA included four main points, three points are meant to protect children in order to avoid prison and then the fourth point is to protect the interests of victims and perpetrators of child. If the victim does not wish to participate, diversion will still run. This philosophical basis is in contrary to the theory of restorative justice and legal protection. In comparison to the Diversion process of Philippines dan Malaysia state, to achieve the ideal form of diversion for criminal offenses minor committed by children in Indonesia is to use a restorative justice approach in a diversion effort. It is supported by the theory of criminal law policy, which is by reformulating and altering the content of Article 9 paragraph (2) of the SPPA.
\end{abstract}

Key words: diversion, restorative justice, victims'rights

\begin{abstract}
Absrtak
Penulisan jurnal berupa hasil penelitian ini dilatarbelakangi oleh tiga permasalahan. Pertama, permasalahan yuridis yang bisa dicermati dari adanya inkonsistensi dalam UU No. 11 tahun 2012 tentang SPPA yakni antara pasal 1 ayat (6) mengenai restorative justice dengan Pasal 9 ayat (2). Hal ini telah mencederai konsep restorative justice bagi korban tindak pidana pencurian ringan. Kedua, permasalahan teoritis, Hak-hak korban harus dilindungi, namun dalam praktek hak tersebut terabaikan. Ketiga, permasalahan sosiologis yang bisa dicermati ialah Tindak pidana pencurian yang dilakukan oleh anak dapat mengganggu kenyamanan dan keamanan di dalam masyarakat. Tujuan penelitian ini Untuk menemukan dasar filosofis pembentukan Pasal 9 ayat (2) UU No. 11 Tahun 2012 tentang SPPA. Untuk menguraikan bagaimana semestinya proses diversi terhadap korban pencurian yang kerugiannya dibawah upah minum provinsi setempat dilaksanakan. Penulisan jurnal ini menggunakan metode penelitian hukum normatif. Dasar pembentukan Pasal 9 ayat (2) Pasal 9 ayat (2) UU No. 11/2012 tentang SPPAterdapat empat
\end{abstract}


poin utama, tiga poin bertujuan untuk melindungi anak agar terhindar dari penjara kemudian poin keempat yaitu melindungi kepentingan korban dan juga pelaku anak. Apabila korban tidak ingin berpartisipasi, diversi tetap akan dijalankan. Dasar filosofis tersebut bertentangan dengan teori restorative justice dan juga teori perlindungan hukum. Setalah melakukan perbandingan Proses diversi dengan Negara Filiphina dan Malaysia, untuk mencapai bentuk ideal diversi untuk tindak pidana pencurian ringan yang dilakukan oleh anak di Indonesia ialah dengan menggunakan pendekatan restorative justice pada upaya diversi. Hal ini didukungoleh teori kebijakan hukum pidana. Dengan mereformulasi untuk merubah isi dari Pasal 9 ayat (2) UU SPPA.

Kata kunci: diversi, restorative justice, hak korban

\section{Latar Belakang}

Terdapat hal penting dalam Negara hukum yaitu adanya komitmen dan penghargaan untuk menjunjung tinggi hak asasi manusia serta jaminan semua warga Negara bersama kedudukannya di dalam hukum.Seperti yang termaktub di dalam Pasal 27 ayat (1) UUD $1945 .^{1}$ Prinsip yang termaktub dalam pasal tersebut idealnya bukan hanya sekedar tertuang di dalam UUD 1945 dan perundangundangan.Tetapi yang paling utama adalah dalam prakteknya atau implementasinya. ${ }^{2}$

Dalam pelaksanaan penegakkan hukum seringkali diwarnai dengan hal-hal yang bertolak belakang dengan prinsip-prinsip UUD tersebut.Contohnya penganiayaan terhadap tersangka untuk mengejar pengakuan, rekayasa perkara, pemerasan, pungutan liar, intimidasi dan sebagainya. Selain itu dari pihak korban juga merasakan terbaikan hak-haknya, antara lain dakwaan lemah, tidak mengetahui perkembangan penanganan perkara, tuntutan ringan,tidak menerima kompensasi dan tidak terpenuhinya hak-hak yang lain. Terhadap hak-hak tersangka atau terdakwa lebih popular diatur dalam Undang-Undang No. 8 Tahun 1981 tentang Hukum Acara Pidana (KUHAP) dan perundang-undangan lain yang terkait, bahkan juga di dalam UndangUndang Dasar 1945. Apabila diteliti, di dalam KUHAP tersebut lebih banyak mengatur hak-hak tersangka dan terdakwa.Untuk hak-hak korban (victim) pengaturannya tidak secara tegas dan tidak sebanyak hak-hak tersangka atau terdakwa.Kemungkinan hak ini disebabkan pihak korban kejahatan/tindak pidana sudah diwakili oleh Negara (penyidik dan penuntut umum). ${ }^{3}$

Dalam proses penegakkan hukum pidana yang berpatokan pada hukum pidana dan acara pidana, Negara yang diwakili oleh organorgannya memiliki hak atau kewenangan untuk menjatuhkan pidana (ius puniendi). Disini jika terjadi tindak pidana, maka

1 Pasal 27 ayat (1) UUD 1945 "segala warga Negara bersama kedudukannya di dalam hukum dan pemerintahan dan wajib menjunjung hukum dan pemerintah itu dengan tidak ada kecualinya".

2 Bambang Waluyo, Viktimologi Perlindungan Korban dan Saksi, Sinar Grafika, Jakarta, 2011, hlm. 1.

3 Ibid., hlm. 2. 
terhadap pelakunya akan di tindak melalui proses peradilan dengan memberi hukuman. Korban tindak pidana serta masyarakat akan secara otomatis diwakili oleh Negara yaitu dengan cara diadili dan dituhkan pidana yang setimpal dengan perbuatan yang telah dilakukan oleh terdakwa.hal ini berbeda dengan zaman dahulu, pada zaman dahulu korban atau keluarganya dapat langsung meminta ganti kerugian atau pembalasan kepada pelaku. Fakta ini seperti yang dikemukakan oleh Hazel B. Kerper ${ }^{4}$

"pada masa lampau, menururt
sejarah perkembangan hukum di
Inggris (Raja sebagai perwakilan
dari Negara) tidak memberikan
perhatian sama sekali terhadap
tindakan kejahatan yang dilakukan
oleh seseorang terhadap orang
lain,terkecuali apabila kejahatan
tersebut dilakukan terhadap Negara
(Raja). Pada saat itu, "pembalasan"
dari seseorang yang dirugikan
terhadap pelaku kejahatan (asas
talio)masih diperkenankan. Bahkan
seluruh keluarga korban dapat
melaksanakan pembalasan."

Berpijak pada sejarah tersebut, dengan berjalannya waktu, kebiasaan itupun dihilangkan.Setelah itu Rajalah yang mengambil alih mewakili Negara.Dan Raja juga yang mengambil peran ganda menjadi hakim dan menjatuhkan hukuman/pidana. Perjalanan sejarah berikutnya, yang tidak sedikit memakan waktu, diantaranya lahir Trias Politica.Melalui kekuasaan yudikatiflah proses peradilan dilakukan agar dapat menciptakan rasa keadilan, kebenaran, serta kepastian hukum. Terlihat bahwa korban (victim) tindak pidana tidak bisa serta merta mengambil haknya begitu saja tanpa menjalani sebuah proses hukum. Inilah konsekuensi Negara hukum, penyelesaian terhadap hak-hak korban juga harus menjalani sebuah proses hukum. Apabila korban langsung meminta atau mengambil (paksa) haknya dari tersangka atau terdakwa dapat disebut sebagai pemerasan, ketika korban melakukan balas dendam atau main hakim sendiri (eigen riechting) maka yang tadinya statusnya adalah sebagai korban dapat berubah menjadi tersangka. Pada proses awal pidana tertentu korban membuat laporan atau pengaduan. Setelah itu Pelaku tindak pidana diproses melalui penyelidikan, penyidikan, penuntutan, pemeriksaan, putusan, dan pelaksanaan putusan pengadilan. Di dalam proses yang begitu sistematis tersebut, dalam hal ini korban dapat menjadi saksi yang dapat memberatkan terdakwa. Sebenarnya berdasarkan Pasal 98 -Pasal 101 Kitab Undang-Undang Hukum Acara Pidana, yang menjadi korban dan orang lain yang dirugikan dapat menutut ganti kerugian, tetapi dalam praktik tidak efektif diterapkan.

Pentingnya perlindungan hukum kepada korban kejahatan secara memadai bukan hanya merupakan isu nasional, melainkan juga merupakan isu internasional.Oleh karena itu, masalah ini perlu memperoleh perhatian yang serius. Pentingnya perlindungan korban 
kejahatan memperoleh perhatian yang serius, dapat dilihat dari bentuknya Declaration of Basic Principles of Justice for Victims of Crime and Abuse Power oleh Perserikatan Bangsa-Bangsa, sebagai hasil dari The Seventh United Nation Conggres on the Prevention of Crime and The Treatment of Offenders, yang berlangsung di Milan, Italia, September 1985. Dalam salah satu rekomendasinya disebutkan: "Offenders or third parties responsible for their behavior should, where appropriate, make fair restitution to victims, their families or dependants. Such restitution should include the return of property or payment for the harm or loss suffered, reimbursement of expenses incurred as a result of the victimization, the provision of services and the restoration of the rights."

Dalam deklarasi di Milan 1985 tersebut, bentuk perlindungan yang diberikan mengalami perluasan tidak hanya ditujukan pada korban kejahatan (victim of crime), tetapi juga perlindungan terhadap korban akibat penyalahgunaan kekuasaan (abuse of power). ${ }^{5}$

Permasalahan mengenai HAM dan keadilan dalamkaitannya terhadap penegakkan hukum pidana bukanlah suatu pekerjaan ringan untuk dapat diimplementasikan. Terdapat berbagai macam peristiwa didalam kehidupan masyarakat yang menunjukan bahwa keadilan dan hak asasi manusia tersebut kurang mendapatkan perhataian yang sungguh-sungguh oleh pemerintah, padahal keadilan dan HAM sangat jelas dalam Pancasila, sebagai ideologi bangsa Indonesia, masalah peri kemanusiaan dan peri kedilan mendapatkan posisi yang begitu urgen sebagai bentuk dari perwujudan Sila Kemanusiaan yang adil dan beradab serta Sila keadilan sosial bagi seluruh rakyat Indonesia. Perlindungan hukum terhadap korban tindak pidana sebagai salah satu contoh kurang diperhatikannya masalah keadilan dan hak asasi dalam penegakan hukum pidana. ${ }^{6}$

Pada setiap penanganan perkara pidana aparat penegak hukum (polisi dan jaksa) sering kali dihadapkan pada kondisi yang mewajibkannya untuk melindungi dua kepentingan yang terkesan saling bertolak belakang, yakni kepentingan korban yang wajib dilindungi untuk memulihkan penderitaanya karena telah menjadi korban kejahatan (secara mental, fisik maupun material), dan kepentingan tertuduh/tersangka sekalipun dia bersalah, tetapi dia tetap sebagai manusia yang mempunyai hak asasi yang harus dijunjung tinggi. Apalagi kalau perbuatannya tersebut belum diputuskan oleh hakim yang menyatakan bahwa pelaku bersalah.Oleh karena itu, pelaku harus dianggap sebagai orang yang tidak bersalah (asas praduga tak bersalah). Dalam penyelesian perkara pidana, hukum seringkali melakukan kekeliruan dengan terlalu mengedepankan hak-hak dari tersangka/terdakwa, sementara hak-hak dari

5 Dikdik M Arif Mansur, Elisatris Gultom, Urgensi Perlindungan Korban Kejahatan Antara Norma dan Realita, Rajawali Pers, Jakarta, 2006, hlm. 23.

6 Ibid., hlm. 24. 
korban diabaikan, sebagaimana dikemukakan oleh Andi Hamzah: "dalam membahas hukum acara pidana khususnya yang membahas HAM, terdapat kecenderungan untuk mengkaji hal-hal yang berkaitan dengan hak-hak tersangka tanpa memerhatikan pula hak-hak para korban. ${ }^{7}$

Di dalam penyelesaian sebuah perkara pidana, seringkali ditemukan korban tindak pidana kurang memperoleh perlindungan hukum secara memadai, baik perlindungan yang bersifat immaterial amupun materiil sebagaimana Geis berpendapat: "to much attention has been paid to effenders and their raights, to neglect of the victim." Korban kejahatan ditempatkan sebagai alat bukti (Alat bukti terdapat dalam pasal 184 KUHAP: keterangan saksi, keterangan ahli, surat, petunjuk, dan keterangan terdakwa) yang memberi keterangan yaitu hanya sebagai saksi sehingga bagi korban hanya memperoleh keleluasaan dalam memperjuangkan haknya adalah kecil.

Korban tindak pidana tidak diberikan kewenangan untuk terlibat secara aktif dalam proses penyidikan dan persidangan sehingga ia kehilangan kesempetan untuk memperjuangkan hak-hak dan memulihkan keadaanya akibat suatu kejahatan. Sebagai contoh apabila seseorang pelaku tindak pidana pencurian mobil berhasil ditangkap aparat kepolisian dan selanjutnya diproses pidana. Pada saat pelaku ditangkap ternyata mobil hasil kejahatannya telah dijual dan hasilnya telah habis dipakai untuk foya-foya bersama teman-temannya. Dengan ditangkapnya pelaku tentunya membawa kegembiraan bagi korban, tetapi pada saat korban tahu bahwa mobil yang dicuri itu telah dijual dan uangnya sudah habis, tentu dengan ditangkapnya pelaku tidak memiliki arti apapun bagi korban karna bagi korban yang lebih penting adalah bagaimana mobil itu dapat kembali dimiliki. Persoalan pelaku kejahatan berhasil ditangkap oleh aparat kepolisian tidak secara langsung berpengaruh terhadap dirinya. ${ }^{8}$

Ketika mobil yang dicuri telah diasuransikan oleh pemiliknya, kerugian yang dideritakorbansedikitbanyakdapatteratasioleh pembayaran klaim dari perusahaan asuransi. Namun, hal yang berbeda akan terjadi pada kasus pencurian ringan yang dilakukan oleh anak yang kemudian korbannya merupakan orang dewasa yang tidak mampu (miskin). Kasus pencurian ringan yang dilakuakn oleh anak ini tentu akan mengganggu kenyamanan dan ketertiban di dalam masyarakat dan perlu mendapat perhatian kusus, hal ini dikarenakan (anak yang berhadapan dengan hukum) sebisa mungkin dihindarkan dari hukuman penjara. Melalui Undang-Undang No. 11 tahun 2012 tentang Sistem Peradilan Pidana Anak yang (selanjutnya disebut UU SPPA) aparat penegak hukum akan berusaha mencari solusi terbaik bagi sang anak. Diversi akan dupayakan secara maksimal oleh pihak penyidik demi 
menghindarkan anak untuk masuk ke dalam SPP (Sistem Peradilan Pidana), karena akibat buruk yang dapat diderita sang anak tersebut (anak yang berhadapan dengan hukum) apabila telah masuk dalam SPPA. Label pencuripun akan diberikan oleh masyarakat kepada sang Anak (Anak yang berhadapan dengan hukum), dan hal ini akan sangat mengagganggu tumbuh kembang sang Anak. Pelabelan terhadap anak dan perlakuannya pada seseorang akan menyebabkan seseorang (anak) itu menerima identitas sebagai pelaku menyinpangan dan menolak self-image konvensional (citra diri yang baik/lazim) ${ }^{9}$. Perubahan (transformasi) indentitas ini pada saatnya akan memunculkan sebuah komitmen pada peningkatan karier individu/seseorang sebagai pelaku menyimpangan. Stigma yang ditentukan secara konvensional (publik), dapat mengucilkan individu/seseorang (anak) dari ketaatan terhadap norma dan pada waktunya akan meningkatan ketertarikan individu/ orang (anak) tersebut pada perilaku-perilaku menyimpang.

Selanjutnya, yang menjadi bahan pertimbangan lain agar sang Anak (anak yang berhadapan dengan hukum) dijauhkan dari proses peradilan pidana anak adalah dikawatirkan apabila anak tersebut diputus bersalah dan kemudian harus menjalani hukuman penjara maka anak tersebut bisa lebih buruk dari keadaan sebelumnya. Karena periaku kejahatan merupakan hal yang dipelajari dari lingkugang sekitar. Perilaku kejahatan identik dengan perilaku nonkejahatan, sebab keduanya merupakan perilaku yang dipelajari. Edwin H. Sutherland berhipotesis bahwa perilaku kriminal itu dipelajari melalui asosiasi yang dilakukan dengan mereka yang melanggar norma-norma masyarakat tremasuk norma hukum. Proses yang dipelajari tadi meliputi tidak hanya teknik kejahatan sesungguhnya namun juga motif, dorongan, sikap dan rasionalisasi yang nyaman atau memuaskan bagi dilakukannya perbuatan-perbuatan anti sosial. ${ }^{10}$ Jadi anak akan yang masuk dalam lemabaga pembinaan khusus anak dikawatirkan akan menambah wawasan kriminalnya lebih luas. Oleh sebab itu anak yang berhadapan dengan hukum semaksimal mungkin dijauhkan dengan sistem peradilan pidana anak dengan diupayakan diversi.

Sebuah konsep baru yang diterapkan pada Sistem Peradilan Pidana Anak (SPPA) yaitu diversi bertujuan untuk menciptakan keadilan restorative ${ }^{11}$. Namun pada Pasal 9 ayat (2) UU SPPA:

"kesepakatan diversi harus mendapatkanm persetujuan korban dan/atau keluarga anak korban serta kesediaan anak dan keluarganya, kecuali untuk:

9 Abintoro Prakoso, Kriminilogi dan Hukum Pidana, Laksbang Grafika, Jember, 2013, hlm. 147.

10 Ibid., hlm. 107.

11 Keadilan restorative adalah penyelesaian perkara tindak pidana dengan melibatkan pelaku, korban, keluarga pelaku/korban, dan pihak lain yang terkait untuk bersama-sama mencari penyelesaian yang adil dengan menekankan pemulihan kembali pada keadaan semula, dan bukan pembalasan. (Pasal 1 angka 6 UU No. 11 Tahun 2012 tentang Sistem Peradilan Pidana Anak). 
a. Tindak pidana yang berupa pelanggaran;

b. Tindak pidana ringan;

c. Tindak pidana tanpa korban; atau

d. Nilai kerugian korban tidak lebih dari upah minimum provinsi setempat."

Pasal 9 ayat (2) UU SPPA ini telah mencederai konsep keadilan restorative, dimana dalam keadilan restorative disebutkan dengan jelas melibatkan pelaku, korban, serta keluarga dari korban maupun pelaku. Namun yang tertuang dari pasal 9 ayat (2) justru meniadakan keberadaan korban berdasarkan sebuah angka upah minimum provinsi.Kerugian yang dialami korban tidak semuanya dapat diukur dengan sebuah nominal (upah minimum provinsi), karena berapapun angka kerugian yang dialami oleh korban, korban tetaplah pihak yang dirugikan. Dan menggunakan upah minimum provinsi sebagai standar untuk mendengarkan pendapat korban sangatlah mencederai rasa keadilan terhadap korban, ketika korban pencurian ringan yang dilakukan oleh anak adalah orang yang tidak mampu (miskin) kehilangan barang yang nilainnya dibawah upah minimum provinsi (UMP) akan berdampak besar bagi korban tersebut, hal ini dikarenakan korban bukan orang kaya, yang ketika kehilangan barang yang nilainya dibawah UMP mereka akan merasa biasa-biasa saja dan akan sangat jauh berbedah dengan yang dirasakan orang tidak mampu. Orang yang pengahasilannya perhari sekitar Rp. 30. 000,00 (tiga puluh ribu rupiah) hanya cukup untuk makan sehari-hari, betapa besar penderitaan korban dengan latar belakang keluarga miskin seperti ini.
Terdapat kasus menarik yang berkitan dengan Pasal 9 ayat (2) UU SPPA, yakni kasus pencurian ringan yang terjadi di desa Sumberejo kec.Batu, yang dilakukan oleh anak yang berinisial AS berusia 16 tahun dan AP yang berusia 17 tahun melakukan pencurian terhadap sebuah tabung gas elpigi 3kg.korban dan warga yang menangkap pelaku anak tersebut langsung membawanya ke Polres Batu. Setelah proses penyidikan selesai dilakukan oleh pihak kepolisian, pelaku anak tersebut dipulangkan oleh pihak kepolisian, karena sesuai Pasal 30 ayat (1) UU SPPA penangkapan terhadap anak dilakukan untuk kepentingan penyidikan paling lama 24 jam. Setelah anak tersebut kembali ke desa tempat tinggalnya, masyrakatpun langsung mendatangi Polres Batu dengan mengajukan keberatan bahwa anak tersebut seharusnya dipenjara.Pihak Penyidik pun memberikan penjelasan mengenai aturan yang berlaku bagi anak yang berhadapan dengan hukum kepada tokoh masyarakat yang mewakili warga desa tempat anak melakukan pencurian tersebut. Setelah diberikan penjelasan mengenai aturan yang berlaku bagi anak yang berhdapan dengan hukum, tokoh maysrakat ini kembali menyampaikan kepada warga desa, namun warga desa tidak puas dengan penjelasan tersebut. Tokoh-tokoh masyarakatpun harus bolak-balik ke Polres Batu sampai tiga kali, penjelasan yang ketiga kali oleh pihak Kepolisian, akirnya masyarakat dapat memahinya. Melihat kejiadian seperti ini, penyidik mengambil sebuah kebijakan dengan 
melibatkan korban pada proses diversi karena khawatir dengan keselamatan pelaku anak tersebut. Meskipun di dalam UU SPPA tidak tidak diatur seperti itu. Proses diversi yang diupaykan berjalan dengan lancar. Korban yang diikutkan dalam proses diversi tersebut menceritkan apa yang dia rasakan sebagai korban dan mendengar langsung penjelasan dari pelaku kenapa dia melakukan pencurian tersebut. Pelakupun meminta maaf kepada korban dan korban dapat memaafkan pelaku. Perlu disadari bahwa sekecil apapun kerugian yang dialami oleh korban, korban harus dilibatkan dan didengar pendapatnya dalam proses diversi, karena itu merupakan bagian dari hak korban dalam proses diversi.

Sudah semestinya aturan yang mengatur mengenai diversi dengan mewajibkan pendekatan restorative justice tidak membedakan korban. Artinya kerugian berapun yang diderita oleh korban, sudah seharusnya dia memperoleh haknya dalam proses diversi, yakni hak untuk ikut serta dalam proses diversi. Seperti yang tersirat dalam penafsiran Pasal 3 ayat (2) dan pasal 5 ayat $(1,2)$ Undang-Undang No 39 tahun 1999 tentang Hak Asasi Manusia: bahwa setiap orang berhak atas pengakuan, jaminan, perlindungan, dan perlakuan hukum yang adil serta mendapat kepastian hukum dan perlakuan yang sama di depan hukum (pasal 3 ayat (2)), bahwa setiap orang diakui sebagai manusia pribadi yang berhak menuntut dan memperoleh perlakuan serta perlindungan yang sama sesuai dengan harkat dan martabat kemanusiaannya di depan hukum. (pasal 5 ayat (1)), dan Bahwa setiap orang berhak mendapat bantuan dan perlindungan yang adil dari pengadilan yang objektif dn tidak berpihak.(pasal 5 ayat (2)). Dan hal ini sesuai dengan Pasal 5 huruf b Undang-Undang No 13 tahun 2006 tentang Perlindungan Saksi dan Korban bahwa, saksi dan korban berhak ikut serta dalam proses memilih dan menentukan bentuk perlindungan dan dukungan keamanan.

Hal ini berarti bahwa sekecil apapun kerugian yang dialami oleh korban, dia harus tetap mendapatkan perlindungan hukum dan perlakuan yang sama didepan hukum. Jika dikaitkan dengan dengan pasal 9 ayat (2) undang-undang no 11 tahun 2012 tentang system peradilan pidana anak, baik korban yang kerugiannya diatas upah minimum provinsi setempat maupun dibawah upah minimum provinsi setempat, seharusnya korban harus tetap didengarkan pendapatnya pada proses diversi karena itu merupakan hak korban yang dijamin oleh undang-undang.

Berdasarkan hal itu perlu dilakukan analisa mengenai Apa yang menjadi dasar filosofis penetapan Pasal 9 ayat (2) UU No. 11 tahun 2012 tentang SPPA serta Bagaimana seharusnya proses diversi dilakukan untuk melindungi korban pencurian ringan yang kerugiannya dibawah upah minimum provinsi setempat Dilakukan di Tingkat Penyidikan.

Penulisan jurnal hasil penelitian ini menggunakan metode penelitian hukum normatif melalui pendekatan perundang undangan serta pendekatan perbandingan. 
Bahan hukum yang digunakan terdiri dari bahan hukum primer yang terdiri dari Undangundang Dasar Negara Republik Indonesia tahun 1945, Undang-undang Nomor 1 Tahun 1946 tentang Kitab Undang-Undang Hukum Pidana, Undang-undang Nomor 11 Tahun 2012 tentang SPPA, Undang-Undang No. 13 tahun 2006 tentang Perlindungan saksi dan korban, Undang-Undang No. 39 Tahun 1999 tentang Hak Asasi Manusia, Perma Nomor 2 tahun 2012 tentang Penyesuaian Batasan Tindak Pidana Ringan Dan Jumlah Denda Dalam KUHP, Juvenile Justice and Welfare Act of 2006 Filiphina, Child Act 2001 Malaysia, bahan hukum sekunder yang terdiri dari buku, jurnal, dan kasus kasus hukum terkait penelitian, dan bahan hukum tersier yang terdiri dari Kamus Besar Bahasa Indonesia, Kamus Bahasa Inggris, Kamus Hukum, dan enseklopedia. Bahan hukum tersebut dikumpulkan berdasarkan tema permasalahan yang telah dikemukakan kemudian dikaji secara mendalam.

\section{Pembahasan}

\section{A. Dasar Filosofis Penetapan Pasal 9 ayat (2) UU No. 11 Tahun 2012 tentang SPPA}

Dari Risalah Pasal 9 ayat (2) UU No. 11 tahun 2012 tentang SPPA, terjadi perdebatan panjang dalam penyusunannya.Ada yang setuju bila persetujuan korban diperlukan dalam diversi untuk tindak pidana ringan, dan ada juga yang setuju korban harus diikut sertakan. Dari perdebatan panjang tersebut, dapat disimpulkan bahwa terdapat beberapa alasan yang menjadi dasar pertimbangan dalam penyusunan Pasal 9 ayat (2) dalam UU SPPA ialahpertama,jikapersetujuan atau izin korban dan keluarga itu dicari, maka akan memperkecil peluang pelaku anak untuk memperoleh diversi. Sedangkan di dalam mandat konvensi hak anak Pasal 40 dikatakan bahwa semua aturan peradilan seharusnya mementingkan kepentingan-kepentingan anak termasuk untuk martabat dan sebagainya, yang tentunya akan terancam jika anak itu dipenjara.

Kedua, sulitnya pencapaian diversi apabila harus meminta persetujuan korban dan akan terjadi diskriminasi terhadap $\mathrm{ABH}$ yang berasal dari keluarga kurang mampu, hal ini dikarenakan ganti rugi yang diajukan oleh pihak keluarga korban terhadap pelaku, ABH yang berasal dari keluarga kurang mampu akan sulit untuk mengakses diversi.

Ketiga, dalam undang-undang ini (UU SPPA) semangat kita bukan memenjarakan anak dalam proses pidana, tetapi bagaimana melakukan suatu pola pembinaan terhadap masalah yang dihadapi anak ketika berhadapan dengan hukum. Apabila harus meminta persetujuan korban, harus ada parameternya (angka kerugian).Agar pencurian sandal jepit tidak perlu masuk didalam penjara.Keempat, pada proses diversi korban harus diberikan kesempatan untuk berpartisipasi. Apabila korban tidak ingin berpartisipasi, diversi tetap akan dijalankan. Karena korban juga perlu dilindungi kepentingannya, kepentingan 
korban ialah ganti rugi. Jadi pada proses diversi tidak akan ditanya apakah kasus ini akan dilanjutkan ke jalur formal atau diversi tetapi pertanyaan kepada korban pada proses diversi ialah Bagaimana bentuk ganti rugi yang diinginkan oleh korban. Bisa jadi hanya dengan perminta maaf dari pelaku saja sudah cukup bagi korban.Bentuk dari ganti rugi terhadap korban bisa sangat fleksibel.

Pedoman Perserikatan Bangsa-Bangsa dalam Rangka Pencegahan Tindak Pidana Remaja Tahun 1990 (United Nation Guidelines fot the Preventive of Juvenile Delinquency, "Riyadh Guedelines"), disebutkan bahwa keberhasilan pencegahan terhadap anak pelaku tindak pidana memerlukan upaya dari seluruh masyarakat guna menjamin perkembangan kea rah proses dewasa secara harmonis dengan menghormati dan mengembangkan kepribadian mereka sejak masa kanak-kanak. ${ }^{12}$

Dengan melihat empat alasan dari proses penyusunan Pasal 9 ayat (2) UU SPPA diatas, terlihat jelas bahwa yang mementingkan kepentingan korban sangatlah kecil. Semua pendapat atau alasannya yang dikemukakan dalam proses perumusan Pasal tersebut lebih menitikberatkan kepada kepentingan pelaku anak. Sudah semestinya Negara memberikan perlindungan hukum bagi warga negaranya, tidak terkecuali untuk korban tindak pidana pencurian yang kerugiannya dibawah UMP. Perlindungan hukum yang dimaksud yakni perlindungan terhadap hak-hak korban. Hak korban dalam diversi ialah hak untuk dikutsertakan dalam proses diversi. Seperti yang sudah dijelaskan pada bagian awal, Restorative Justice menurut Tony Marshall yang diadopsi oleh Kelompok Kerja Peradilan Anak PBB, adalah suatu proses dimana semua pihak yang berhubungan dengan tindak pidana tertentu bersama-sama memecahkan masalah dan bagaimana menangani akibat dimasa yang akan datang/ implikasinya dimasa depan. Konsep Restorative Justice dari UNICEF menitik beratkan kepada keadilan yang dapat memulihkan, yaitu memulihkan bagi pelaku tindak pidana anak, korban dan masyarakat yang terganggu akibat adanya tindak pidana tersebut. $^{13}$

Pihak pelaku yang memberikan penjelasan ataupun alasan-alasan mengenai kejahatan yang dilakukannya sangat mengharapkan pihak korban untuk dapat menerima dan memahami kondisi dan penyebab mengapa pihak pelaku melakukan tindak pidana yang menyebabkan kerugian pada korban. Selanjutnya dalam penjelasan pelaku juga menjelaskan tentang bagaimana dirinya bertanggung jawab terhadap korban dan masyarakat atas perbuatannya tersebut.Selama pihak pelaku menjelaskan tentang perbuatan yang dilakukannya dan sebab-sebab mengapa sampai tindak pidana tersebut dilakukan pelaku, korban wajib mendengarkan dengan seksama penjelasan dari pelaku.Setelah itu

12 Pedoman Perserikatan Bangsa-Bangsa dalam Rangka Pencegahan Tindak Pidana Remaja Tahun 1990 (United Nation Guidelines fot the Preventive of Juvenile Delinquency, "Riyadh Guedelines"), Resolusi No. 45/122.1990, Butir 2 .

13 Wagiati dan Melani, Op.cit., hlm. 134. 
pihak korban dapat memberikan tanggapan atas penjelasan pelaku.Disamping itu juga, juga hadir pihak masyarakat yang mewakili kepentingan masyarakat.Wakil masyarakat tersebut memberikan sebuah gambaran mengenai dampak yang diakibatkan dengan terjadinya tindak pidana yang dilakukan oleh pelaku.Dalampaparannyatersebut,masyarakat mengharapkan agar pelaku melakukan suatu tindakan atau perbuatan untuk memulihkan kembali keguncangan atau kerusakan yang timbul karena perbuatnnya. ${ }^{14}$

Di dalam Teori Restoratif Justice, proses penyelesaian tindakan pelanggaran hukum yang terjadi dilakukan dengan membawa korban dan pelaku (tersangka) bersama-sama duduk dalam satu pertemuan untuk bersamasama berbicara.Dalam pertemuan tersebut mediator meberikan kesempatan pada pihak pelaku untuk memberikan gambaran yang sejelas-jelasnya mengenai tindakkan yang telah dilakukannya. Proses pemulihan menurut konsep Restorative Justice adalah melalui diversi, yaitu pengalihan atau pemindahan dari proses peradilan ke dalam proses alternatif penyelesaian perkara, yaitu melalui musyawarah pemulihan atau mediasi. Langkah pengalihan dibuat untuk menghindrakan anak dari tindakan hukum selanjutnya dan untuk dukungan komunitas, disamping itu pengalihan bertujuan untuk mencegah pengaruh negatif dari tindakan hukum berikutnya yang dapat menimbulkan stigmatisasi. Apabila perkanya tidak dapat diselesaikan secara mediasi Sistem Peradilan Pidana Anak harus mengacu pada due process of law ${ }^{15}$, sehingga Hak Asassi Anak yang diduga melakukan tindak pidana dan/atau telah terbukti melakukan tindak pidana dapat dilindungi. ${ }^{16}$

Restorative Justice sebetulnya bukan merupakan hal asing dalam penyelesaian tindak pidana di indonesia. Proses ini pernah berlaku dan sampai saat ini masih berlaku di daerah-daerah tertentu, yaitu penyelesaian menurut hukum adat. Menurut Soepomo penyelesaian menurut hukum adat menghendaki pengembalian keseimbangan di dalam masyarakat, atau pemulihan keadaan. ${ }^{17}$ Selain dalam hukum adat, musyawarah dalam menyelesaikan perkara pidana juga dikenal dalam hukum islam, yaitu apabila korban atau keluarga korban memaafkan pelaku kejahatan, dengan membayar (diat) yang dilakukan oleh pelakukepada korban. ${ }^{18}$

14 Marlina, Peradilan Pidana Anak di Indonesia, Medan, Refika Aditama, 2009, hlm. 180.

15 Due process of law diartikan penegakan hukum dengan cara tidak bertentangan dengan hukum. Istilah due process of law mempunyai konotasi bahwa segala sesuatu harus dilakukan secara adil.

16 Op.cit., Wagiati Soetedjo, Melani, hlm. 135.

17 Ibid., hlm. 135.

18 Al-Qur'an Surat Al Baqarah: 178 “wahai orang-orang yang beriman! Diwajibkan atas kamu (melaksanakan) Qishas berkenaan dengan orang yang dibunuh.Orang merdeka dengan orang merdeka, hamba sahaya dengan hamba sahaya, perempuan dengan perempuan. Namun, siapa yang memperoleh maaf dari saudaranya, hendaklah ia mengikuti dengan baik, dan membayar diat (tebusan) kepadanya dengan baik (pula). Yang demikian itu adalah keringanan dan rahmat dari Tuhanmu.Siapa yang melampaui batas setelah itu, maka ia akan mendapat azab yang sangat pedih". 
Restorative Justice menawarkan solusi terbaik dalam menyelasaikan kasus kejahatan yakni dengan memberikan keutamaan pada inti permasalahan dari suatu kejahatan. Penyelesaian yang penting untuk diperhatikan adalah meperbaiki kerusakan atau kerugian yang disebabkan terjadinya kejahatan tersebut.Perbaikan tatanan sosial masyarakat yang terganggu karena peristiwa kejahatan merupakan bagian penting dari konsep restorative justice.Konsep restorative justice bukanlah sebuah konsep yang matang dan sempurna, untuk menerapkannya dengan baik dalam sebuah tatanan masyarakat suatu Negara harus dibangun konsep yang sesuai dengan akar budaya masyarakat Negara tersebut. Ketika konsep ini akan diterapkan maka bayak pertimbangan yang harus disesuaikan dengan budaya dari masyarakat, karena salah satu pihak yang menjadi pelaksanaannya adalah masyarakat itu sendiri. ${ }^{19}$

Penyelesaian perkara dengan restorative justice menitikberatkan pada kerusakan yang berakibat pada korban atau para korban dan masyarakat terdekan yang menekankan kepentingan dari pihak. Inti dalam proses restorative justice yaitu korban, masyarakat, dan pelaku untuk membangun tanggapan yang bersifat menyembuhkan tindakan kejahatan.

Terlihat jelas bahwa konsep restorative itu bukan hanya memulihkan keadaan pelaku anak dan masyarakat, tetapi juga memulihkan keadaan bagi korban. Pada suatu tindak pidana, korban merupakan pihak yang paling dirugikan, Korban kejahatan merupakan individu yang telah mengalami penderitaan berupa kerugian sebagai pengaruh atau akibat suatu tindak pidana dan atau yang rasa keadilannya secara langsung telah terusik sebagai pengaruh atau akibat pengalamnnya dijadikan sasaran tindak kejahatan. ${ }^{20}$

Diversi merupakan bentuk perlindungan hukum yang diberikan oleh Negara yang tertuang didalam UU SPPA terhadap pelaku dan juga korban.Artinya ada dua pihak yang dilindungi oleh Negara yakni korban dan juga pelaku. Perlindungan Hukum sebagai pengayoman terhadap HAM yang dirugikan orang lain dan perlindungan itu diberikan untuk masyarakat agar mereka bisa menikmati semua hak-hak yang diberikan oleh hukum. ${ }^{21}$ Perlindungan Hukum sebagai perlindungan terhadap harkat dan martabat, serta pengakuan terhadap HAM yang dimiliki oleh subyek hukum berdasarkan ketentuan hukum dari kesewenangan. ${ }^{22}$ Sudah jelas terlihat bahwa dalam proses diversi wajib menggunakan pendekatan restorative justice, yang didalam pendekatan tersebut terdapat hak-hak korban yang harus dilindungi oleh Negara. Haknya ialah hak untuk diikut sertakan dalam sebuah proses diversi. Negara semestinya

19 Op.cit., Wagiati Soetedjo, Melani, hlm. 135.

20 Rena Yulia, Op.cit., hlm. 51.

21 Satjipto Raharjo, Penyelenggaraan Keadilan dalam Masyarakat yang Sedang Berubah, Jurnal Masalah Hukum, 1993, hlm. 74.

22 Philipus M. Hadjon, Perlindungan Hukum bagi Rakyat Indonesia, Bina Ilmu, Surabaya, 1987, hlm. 25. 
memberikan perlindungan terhadap korban tindak pidana pencurian ringan, agar korban dapat menikmati hak yang semstinya dia peroleh, karena itu merupakan tugas dan tangung jawab Negara terhadap warga negaranya.

Pelaku/ABH yang melakukan tindak pidana pencurian ringan baik yang berasal dari keluarga mampu atau keluarga kurang mampu tetap diberi kesempatan untuk dapat diupayakan diversi. Negara tidak memandang latar belakang pelaku berasal dari keluarga yang kaya ataupun yang miskin, pelaku akan diperlakukan sama, yakni sama-sama akan diupayakan diversi.

Tetapi terdapat hal yang berbeda dengan korban atau victim, dengan rumusan Pasal 9 ayat (2) di dalam UU N0.11 tahun 2012 tentang SPPA ini terlihat diskriminasi yang dilakukan Negara terhadap korban tindak pidana pencurian ringan yang nilai kerugiannya dibawah UMP. Korban yang jumlah kerugiannya dibawah UMP tidak diikutsertakan dalam proses diversi. Korban hanya boleh berpartisipasi dalam proses diversi apabila kerugiannya diatas UMP.

Padahal dalam Undang-Undang Dasar Negara Republik Indonesia tahun 1945 Pasal 28D ayat (1) disebutkan bahwa "setiap orang berhak atas pengakuan, jaminan, perlindungan, dan kepastian hukum yang adil serta perlakuan yang sama didepan hukum". Artinya korban dengan nilai kerugian diatas UMP maupun yang dibawah UMP harus tetap diikutsertakan dalam proses diversi. undang-undang dasar menjamin akan hal ini, dan sebenarnya hal ini sudah diatur juga dalam undang-undang no 11 tahun 2012 ini dalam Pasal 1 ayat (6), namun kemudian diberi pengecualian dalam Pasal 9 ayat (2). Dan juga perlu diketahui bahwa pada tahun 2014 pemerintah Indonesia mendefinisikan garis kemiskinan dengan pendapatan perbulan (per kapita) sebanyak Rp.312, 328 jumlah tersebut setara dengan USD \$25 yang dengan demikian berarti standar hidup yang sangat rendah. ${ }^{23}$ Artinya rata-rata penduduk Indonesia masih jauh dari kata sejahtera.Masih banyak penduduk Indonesia yang berpenghasilan jauh dibawah UMP.Ketika masyarakat yang kurang mampu menjadi korban pencurian ringan, misalnya dia kehilangan gas elpiji $3 \mathrm{~kg}$ yang hanyga sekitar Rp. 300.000, 00 (tiga ratus ribuh rupiah) maka itu merupakan nilai yang cukup besar bagi mereka yang penghasilannya hanya cukup untuk makan sehari-hari.Dengan aturan seperti ini, korban tidak dapat berbuat apa-apa, dia hanya bisa pasrah, berharap pelaku dapat memberikan ganti rugi.Apabila pelaku tidak dapat memberikan ganti rugi, korbanpun hanya bisa berlapang dada.

Apabila hal ini dibiarkan terus menerus, maka tidak menutup kemungkinan masyarakat tidak akan percaya lagi terhadap hukum di Indonesia, dan besar kemungkinan korban akan mengadili sendiri pelaku tindak

23 Van der Schaar, Kemiskinan Di Indonesia, http:// indonesia-investments.com, diakses 2 Juni 2015 pukul 09.00 WIB. 
pidana pencurian ringan tersebut, karena merasa kecewa terhadap hukum di Indonesia. Mereka yang menjadi korban tindak pidana pencurian ringan ketika melaporkan kepada aparat penegak hukum, korban berharap akan memperoleh perlindungan dari Negara, berupa perlindungan terhadap hak-haknya sebagai korban dan juga berharap akan memperoleh ganti rugi, akan tetapi yang terjadi ialah sebaliknya. Mereka yang kerugiannya dibawah UMP atau yang termasuk dalam tindak pidana ringan tidak perlu diikutsertakan dalam proses diversi. Seperti yang sudah di sampaikan pada bagian kajian pustaka mengenai tindak pidana pencurian ringan, disitu dijalaskan bahwa dengan kerugian Rp.2.500.000,00 (dua juta lima ratus ribu rupiah) dapat digolongkan sebagai tindak pidana pencurian ringan. Tentu angka ini merupakan angka yang cukup besar bagi mereka yang berpenghasilan hanya cukup untuk makan sehari-hari.Apabila Negara ingin melindungi $\mathrm{ABH}$ melalui undang-undang sistem peradilan pidana anak, maka yang perlu diingat ada korban yang juga harus dilindungi.

Pada proses diversi, belum tentu pelaku dapat memberi ganti rugi kepada korban, karna mungkin hasil dari tindak pidana tersebut sudah habis digunakan, maka korban dituntut untuk bisa bersabar dan mengerti keadaan seperti ini, karena yang melakukannya adalah Anak. Tetapi para pembuat undang-undang ini seakan lupa bahwa korban tindak pidana juga punya keluarga, tentu juga punya keperluan yang cukup banyak. Apalagi yang menjadi korban keluarga miskin, sudah hidup susah ditambah menjadi korban pencurian ringan, maka pada posisi seperti ini, anak yang melakukan pencurian ringan sangat rentan mendapat tindakan main hakim sendiri oleh korban.

Lewellyn dan Howse melakukan sebuah penelitian pada tahun 1998 dikatakan bahwa keikhlasan hati, kejujuran dalam sebuah pertemuan tatap muka antarakorban dan pelaku sebagai elemen utama dari proses restorative justice. ${ }^{24}$ Keikhlasan artinya ada pengakuan tulus dari pelaku untuk menyadari kesalahan yang telah dilakukannya terhadap korban dan korban dengan ketulusan hati memahami dan mencoba memberikan rasa maafnya kepada pelaku yang telah melakukan tindak pidana sehingga merigikan diri korban, baik secara materill maupun secara nonmaterial. Kemudian nilai yang harus diutamakan selain rasa keikhlasan adalah nilai kejujuran.Nilai kejujuran ini memberikan kemudahan kepada semua pihak untuk memahami mengapa sampai terjadi suatu tindak pidana oleh seseorang dan masyarakat dapat memberikan masukan dan perbaikan untuk memecahkan dan mencari jalan penyelesaian yang terbaik untuk semua pihak, baik korban, pelaku ataupun masyarakat.

Pada sebuah proses diversi, restorative justice wajib diutamakan. Kewajiban pendekatan restorative justice ini bukan tanpa alasan, hal ini sangat dibutuhkan dalam proses 
diversi untuk memberikan hak pelaku dan juga korban dalam proses diversi tersebut. Apabila pelaku, korban, mediator, beserta pihak-pihak yang terkait duduk bersama untuk mencari solusi terbaik untuk masalah yang dihadapi, pelaku dapat menjelaskan kepada korban mengapa dia melakukan perbuatan tersebut serta dapat secara langsung menyampaikan permintaan maafnya, kemudian korban juga dapat mengeluarkan isi hatinya kepada si pelaku, kemudian ditambah dengan penjelasan dari mediator kepada korban mengenai pentingnya diversi ini bagi $\mathrm{ABH}$ untuk masa depannya, besar kemungkinan korban akan lebih bisa menerima meskipun tanpa disertai ganti rugi.

Selain itu, dengan diikutsertakan korban dalam proses diversi, dengan penjelasan pelaku, mediator dapat menyapaikan kepada korban bahwa korban ini tergolong jenis korban apa. Karena terdapat beberapa jenis korban tindak pidana yakni, Latent victims (mereka yang mempunyai sifat karakter tertentu sehingga cenderung menjadi korban). Procative victims (mereka yang menimbulkan rangsangan terjadinya kejahatan). Participating victims, (yakni mereka yang dengan tingkahlakunya mempermudah dirinya untuk dijadikan korban).Dan False victim, (mereka yang menjadi korban karena perbuatan yang dibuatnya sendiri). ${ }^{25}$ Dengan penjelasan seperti ini, tentu akan memberikan edukasi kepada korban dan juga masyarakat yang terlibat dalam proses diversi tersebut, korban akhirnya juga mengerti mengapa dia menjadi korban suatu tindak pidana. Penjelasan ini sangat berguna bagi si korban agar dapat lebih berhati-hati lagi kedepannya agar tidak menjadi korban lagi dikemudian hari. Masyarakat yang hadir (tokoh masyarakat) juga dapat menyampaikan kepada anggota masyarakat edukasi yang didapat dari proses diversi tersebut. Artinya dapat dilakukan upaya pencegahan kejahatan secara preventif oleh masyarakat terhadap suatu tindak pidana.

\section{B. Bentuk Ideal Proses Diversi untuk Melindungi Korban Pencurian Ringan yang Kerugiannya dibawah Upah Minimum Provinsi}

\section{Setempat}

Dari perbandingan antara Negara Indonesia dengan Negara Malaysia dan Filiphina, terdapat perbedaan dalam upaya diversi. Berikut ini merupakan perbedaan diversi antara ketiga Negara tersebut:Dari tabel diatas dapat dilihat bahwa Filiphina dan Malaysia dapat menempatkan kepentingan pelaku anak dan juga korban secara merata. Artinya selain mengutamakan kepentingan pelaku, kedua Negara tersebut juga memikirkan kepentingan korban. Hal ini terlihat dari proses diversi dari kedua Negara tersebut. Seperti yang penulis tulis diatas, Negara Filiphina melakukan diversi untuk semua tindak pidana yang dilakukan oleh anak, dan menggunakan pendekatan keadilan restorative untuk semua tindak 
Tabel 1. Perbandingan Diversi antara Negara Indonesia, Filiphina, dan Malaysia. ${ }^{26}$

\begin{tabular}{|l|l|l|l|}
\hline & \multicolumn{1}{|c|}{ Indonesia } & \multicolumn{1}{c|}{ Malaysia } & \multicolumn{1}{c|}{ Filiphina } \\
\hline Undang-Undang & $\begin{array}{l}\text { UU No. 11 tahun 2012 } \\
\text { tentang SPPA }\end{array}$ & $\begin{array}{l}\text { Child Act 2001 } \\
\text { Malaysia }\end{array}$ & $\begin{array}{l}\text { Juvenile Justice and } \\
\text { Welfare Act of 2006 } \\
\text { (Republic Act No. } \\
\text { 9344) Filiphina }\end{array}$ \\
\hline Usia & 12-18 Tahun & 10-18 Tahun & 7-16 Tahun \\
\hline $\begin{array}{l}\text { Tindak Pidana Yang } \\
\text { Diversi }\end{array}$ & $\begin{array}{l}\text { Tindak pidana yang } \\
\text { ancamannya dibawah 7 } \\
\text { tahun dan bukan residivis } \\
\text { (Pasal 7 ayat (2)) }\end{array}$ & $\begin{array}{l}\text { Untuk semua jenis } \\
\text { tindak pidana, kecuali } \\
\text { dengan ancaman } \\
\text { hukuman mati (Section } \\
\text { 11(5)) }\end{array}$ & $\begin{array}{l}\text { Untuk semua jenis } \\
\text { tindak pidana } \\
\text { (Section 4 (i) dan } \\
\text { Section 4 (q) }\end{array}$ \\
\hline kesepakatan Diversi & $\begin{array}{l}\text { a. tindak pidana yang be- } \\
\text { rupa pelanggaran; } \\
\text { b. tindak pidana ringan; } \\
\text { c. tindak pidana tanpa } \\
\text { korban; atau } \\
\text { d. nilai kerugian korban } \\
\text { tidak lebih dari nilai } \\
\text { upah minimum provin- } \\
\text { si setempat. } \\
\text { (Pasal 9 ayat (2)) }\end{array}$ & $\begin{array}{l}\text { Dilaksanakan pada } \\
\text { setiap proses diversi } \\
\text { (Section 86 (5)) }\end{array}$ & $\begin{array}{l}\text { Dilaksanakan pada } \\
\text { setiap proses diversi } \\
\text { (Section 23) }\end{array}$ \\
\hline $\begin{array}{l}\text { Kelemahan Diversi } \\
\text { Pada Tiap-Tiap } \\
\text { Negara }\end{array}$ & $\begin{array}{l}\text { Tindak pidana yang } \\
\text { ancamannya dibawah 7 } \\
\text { tahun dan bukan residivis } \\
\text { (Pasal 7 ayat (2)) }\end{array}$ & $\begin{array}{l}\text { Diversi tidak dapat } \\
\text { diberikan kepada } \\
\text { pelaku anak yang } \\
\text { diancam dengan } \\
\text { hukuman mati (Section } \\
\text { 11(5)) }\end{array}$ & $\begin{array}{l}\text { lantuk ancaman hu- } \\
\text { kuman diatas 6 tahun } \\
\text { penara, diversi hanya } \\
\text { ka persidangan. } \\
\text { (Section 23(3)) }\end{array}$ \\
\hline
\end{tabular}

\section{Sumber: UU No. 12 Tahun 2012}

pidana, begitupun dengan Negara Malaysia. Negara Malaysia juga mengupayakan diversi untuk semua tindak pidana yang dilakukan oleh anak, dan menggunakan pendekatan restorative justice dalam proses diversi. Artinya kedua Negara tersebut melibatkan pelaku, korban, keluarga pelaku dan korban dan pihak-pihak lain yang berkenptingan dengan suatu tindak pidana yang terjadi untuk mencapai kesepakatan dan penyelesaian ${ }^{27}$ pada setiap proses diversi tanpa memilah tindak pidana yang dilakukan. Kedua Negara tersebut benar-benar menerapkan keadilan restorative dalam proses diversi. Sedangkan tabel yang menjelaskan mengenai pelaksaan diversi di Indonesia, terlihat hanya melindungi kepentingan pelaku dan korban khusu untuk nilai kerugian diatas UMP dan bukan tindak pidana ringan.

26 Sumber: UU No. 12 Tahun 2012 tentang SPPA, Juvenile Justice and Welfare Act of 2006 (Republic Act No. 9344) Filiphina, dan Child Act 2001 Malaysia.

27 Marlina, Op.cit., hlm. 23. 
Dengan melihat proses diversi dari Negara Filiphina dan Malaysia, hal ini dapat menjadi sebuah bahan perbandingan bagi Negara Indonesia untuk memperbaiki pengaturan proses diversi yang ada dalam sistem peradilan pidana anak, diversi yang bukan hanya mementingkan kepentingan pelaku anak, tetapi juga korban. Oleh karena itu, penulis ingin membuat formulasi terhadap aturan yang mengatur diversi dalam UndangUndang Sistem Peradilan Pidana Anak Indonesia.

Dalam teori kebijakan hukum pidana, Barda Nawawi Arif mengemukakan hubungan antara penal policy dengan upaya penanggulangan kejahatan, pencegahan dan penaggulangan kejahatan harus digunakan dengan pendekatan integral dan ada keseimbangan antara "penal" dan "non penal". Pencegahan dan pendekatan kejahatan dengan sarana "penal" merupakan "penal policy" atau "penal law enforcement policy" yang fungsionalisasi dan atau operasionalisasinya melalui beberapa tahap, yaitu:
a) Formulasi (kebijakan legislasi)
b) Aplikasi (kebijakan yudikatif/yudicial) ${ }^{28}$
c) Eksekusi (kebijakan eksekutif/ administrasi $^{29}$

Menurut Barda Nawawi Arif, usaha dan kebijaksanaan dapat menghasilkan suatu ketentuan hukum pidana yang baik pada dasarnya tidak dapat dipisahkan dari tujuan penaggulangan kejahatan dengan menggunakan pidana (penal). Usaha penanggulangan kejahatan dengan hukum pidana yang pada dasarnya juga merupakan bagian dari usaha penegakan hukum (khususnya dalam penegakan hukum pidana). Oleh karena itu sering pula disebutkan bahwa kebijakan hukum pidana merupakan bagian dari kebijakan penagakan hukum (law inforcement policy $)^{30}$.

Usaha penaggulangan kejahatan melalui pembuatan undang-undang (hukum) pidana pada hakekatnya juga merupakan bagian integral dari usaha perlindungan masyarakat. Dengan demikian seandainya kebijakan penanggulangan kejahatan (politik kriminal) dilakukan dengan menggunakan sarana "penal" (hukum pidana), maka kebijakan hukum pidana (penal policy), khususnya pada tahap formulasi/kebijakan legislasi yang merupakan tugas dari aparat pembuat undangundang (legislatif), harus memperhatikan dan mengarah pada tercapainya tujuan dari kebijakan sosial berupa "social welfare" (kesejahteraan masyarakat) dan "social defence" (perlindungan masyarakat). ${ }^{31}$

\footnotetext{
28 Tahap aplikasi yaitu tahap penerapan hukum pidana oleh aparat-aparat penegak hukum mulai dari kepolisian sampai pengadilan, yang dapat disebut juga tahap yudikatif, Muladi dalam Maidin Gultom, Perlindungan Hukum Terhadap Anak, Refika Aditama, Bandung, 2008, hlm. 17.

29 Tahap eksekusi yaitu tahap perlaksanaan hukum pidana yang dapat disebut juga dengan tahap kebijaksanaan eksekutis atau administrasi, Ibid.

30 Barda Nawawi, Bunga Rampai Kebijakan Hukum Pidana, Op.cit., hlm. 29.

31 Barda Nawawi Arif, Kebijakan Legislatif dalam Menaggulangi Kejahatan, Op.cit., hlm. 73-74.
} 
Penggunaan teori kebijakan hukum pidana pada tahapan formulasi untuk merumuskan kembali Pasal 9 ayat (2) Undang-Undang Sistem Peradilan Pidana Anak. Karena Pasal tersebut tidak sesuai dengan konsep restorative justice, Pasal tersebut tidak melindungi hak-hak korban dalam proses diversi untuk kerugian dibawah UMP dan tindak pidana ringan. Hal ini tentu melanggar ketentuan Undang-Undang Dasar Negara Kesatuan Republik Indonesia yang menyatakan bahwa setiap orang memiliki hak untuk dapat memperoleh perlindungan hukum yang adil serta perlakuan hukum yang sama di depan hukum. Penggunaan tahap formulasi ini bertujuan mewujudkan kembali apa-apa yang menjadi hak-hak korban pada proses diversi, untuk melindungi hak-hak korban dalam proses diversi pada tindak pidana yang kerugiannya dibawah UMP atau tindak pidana ringan (termasuk tindak pidana pencurian ringan). Formulasi yang dibuat pada dasarnya ingin meletakkan Pendekatan keadilan restoratif (restorative justice) pada Pasal 9 ayat (2) sehingga semua tindak pidana yang dilakukan oleh anak baik yang kerugiannya dibawah UMP maupun untuk tindak pidana ringan, akan diupayakan diversi dengan pendekatan restorative justice, tidak ada lagi diskriminasi terhadap korban tindak pidana pencurian ringan. Karena hukum itu melayani/ melindungi semua orang tanpa diskriminasi, ${ }^{32}$
Dasar pijak perspektif restorative justice adalah bahwa konsep kejahatan merupakan perbuatan yang melanggar pertama dan terutama adalah hak perseorangan (yakni korban kejahatan).Disamping melanggar masyarakat, Negara, dan kepentingan pelanggar itu sendiri.Jadi, setiap terjadinya pelanggaran hukum pidana sesungguhnya ada empat kepentingan yang terkait, yaitu orang yang terlanggar haknya (korban kejahatan), masyarakat, Negara, dan pelanggar itu sendiri.Orang yang terlanggar haknya (korban kejahatan) adalah sebagai pihak pertama yang berkepentingan.Oleh sebab itu, sistem peradilan pidana harus mengakses keempat kepentingan itu dengan menempatkan korban kejahatan sebagai kepentingan yang utama. $^{33}$ Van Ness mengkristalisasikan pondasi utama teori keadilan restorative justice dalam proposisi: pertama,kejahatan merupakan konflik utama antara individu yang menyebabkan kerugian terhadap korban, masyarakat, dan pelanggar itu sendiri. Kedua, tujuan harus dicapai dalam proses peradilan pidana harus merekonsiliasi pihak-pihak yang terkait sambil memperbaiki kerugian yang diakibatkan oleh suatu kejahatan. Dan ketiga, proses peradilan pidana harus memfasilitasi partisipasi aktif para korban, pelanggar dan masyarakat, tidak semestinya harus didominasi oleh pemerintah kemudian mengeluarkan yang lainnya. ${ }^{34}$ yang disampaikan oleh Van

32 Romli Atmasasmita, Teori dan Kapita Selekta Kriminologi, Refika Aditama, Surabaya, 1992, hlm. 121. 
ness merupakan hal penting yang harus diperhatikan dalam penyusunan sebuah aturan yang mengutamakan pendekatan restorative justice. Dalam menggunakan pendekatan restorative justice jangan separuh hati, artinya jangandibeda-bedakan. Misalnyauntukkorban tindak pidana yang kerugian di bawah UMP atau untuk tidank pidana ringan (pencurian ringan) tidak perlu dilibatkan dalam proses diversi yang menggunakkan pendekatan restorative justice. UU SPPA seakan masih menggunakan separuh pendekatan retirbutif justice.Karena salah satu cirri pendekatan retirbutif justice ialah pada posisi korban hanya Negara dan tidak mengakui adanya korban lain, orang yang menderita langsung karena kejahatan diposisikan sebagai saksi. ${ }^{35}$ Padahal semangat yang diusung UU SPPA ialah murni pendekatan restorative justice.

Perlu diketahui bahwa ada hal penting yang seakan dilupakan oleh penyusun UU SPPA, yakni asas persamaan dimuka hukum. Hal termuat di dalam Pasal 5 ayat (1) UndangUndang Pokok Kehakiman dan juga di dalam KUHAP, penjelasan umum butir ke tiga. ${ }^{36} \mathrm{Di}$ dalam pasal-pasal tersebut menjadi pedoman tidak hanya untuk mengadili dimuka sidang, tetapi juga dimulai dari taraf penyelidikan. ${ }^{37}$

Bekerja hukum diharapkan dengan tidak membeda-bedakan orang tanpa kecuali, tanpa membedakan ras, agama, jenis kelamin, status ataupun jumlah kerugian yang diderita korban. Kesamaan kedudukan di muka hukum tanpa diskriminasi merupakan asas perlindungan hukum terhadap tindakan melawan hukum yang diperbuat terhadap korban.Hal ini diarahkan untuk melindungi korban dari perbuatan diskriminasi. ${ }^{38}$

Dengan adanya Pasal 9 ayat (2) UU SPPA ini, negara telah melakukan diskriminasi terhadap warga negaranya sendiri, khususnya terhadap korban yang kerugiannya dibawah UMP atau untuk tindak pidana pencurian ringan. Kerugian yang dialami oleh korban tidak bisa dijadikan patokan untuk sebuah proses diversi. Artinya, sekecil apapun kerugian yang diderita korban, dia tetaplah pihak yang paling dirugikan.Lagipula, kita tidak bisa menilai korban hanya dari nominalnya saja. Hal itu sungguh mencederai rasa keadilan bagi korban, kerugian dengan nominal yang sama belum tentu dampak yang dirasakan sama pula. Hal ini dikarenakan tidak semua orang mempunyai kekuatan ekonomi yang memadai (mampu). Contohnya seorang buruh yang menjadi korban tindak pidana pencurian dengan kerugian sebesar Rp.500.000 (lima ratus ribuh rupiah) tentu akan sangat berbeda dampaknya apabila yang menjadi korban tersebut merupakan anggota

35 Ibid., hlm. 188.

36 KUHAP, Butir ke 3: "Perlakuan yang sama atas diri setiap orang di muka hukum dengan tidak mengadakan pembedaan perlakuan".

37 Maya Indah, Perlindungan Korban Suatu Perspektif Viktimologi dan Kriminologi, Kencana Prenadamedia Group, Jakarta, 2014, hlm. 147.

38 Ibid. 
DPR. Bagi anggota DPR, nominal tersebut belum cukup untuk biaya bensinya sebulan, tetapi bagi buruh itu sudah mampu untuk dapat memenuhi kebutuhan hidupnya beserta keluarganya untuk beberapa hari kedepan.

Jadi untuk mendapat proses diversi yang ideal pada tindak pidana pencurian ringan yang dilakukan oleh anak yakni dengan mereformulasi Pasal 9 ayat (2) UU SPPA menjadi: "Untuk memperoleh kesepakatan pada proses diversi, diwajibkan untuk memperoleh persetujuan dari korban, terkecuali untuk tindak pidana yang berupa pelanggaran dan tindak pidana tanpa korban".

Penanggulangan kejahatan dengan menggunakan sarana hukum pidana secara prosedural akan dimulai dari tingkat kepolisian, baik sebagai penyelidik maupun sebagai penyidik. Artinya, penanggulangan kejahatan dengan menggunakan saran hukum pidana selalu dimulai dari tingkat kepolisian. Sebagai bagian dari sub-sistem peradilan pidana kepolisian merupakan lembaga hukum yang mempunyai kewenangan yang begitu luas dalam hal terjadinya kejahatan. Kepolisian juga sebagai lembaga yang mengawali bekerjanya system peradilan pidana. Sebgai lembaga hukum yang mengawali bekerjanya system peradilan pidana, kinerja kepolisian sangat menentukan arah penegakkan hukum pidana. Di tangan lembaga inilah pelaku tindak pidana akan memulai diperiksa sebagai tersangka. Dengan demikian pengalaman pertama dalam proses peradilan pidana bagi seorang tersangka ialah bersentuhan dengan aparat kepolisian. ${ }^{39}$

Oleh karena itu aturan mengenai diversi ini harus benar-benar mengutamakan kepentingan pelaku anak dan juga korban.Jika aturannya sudah dapat menjamin kepentingan korban dan pelaku, penyidik (kepolisian) dapat lebih mudah untuk melakukan upaya diversi.Seperti contoh kasus yang dipaparkan pada bagian awal, pihak penyidik mengambil sebuah kebijakan untuk mengikutsertakan korban dalam kasus tindak pidana pencurian ringan, pahal hal tersebut tidak tertuang atau diatur dalam UU SPPA.Namun dengan dasar untuk melindungi pelaku anak dan sebagai antisipasi pihak penyidik agar pelaku anak tidak menjadi korban luapan emosional pihak korban karena kecewa dengan keputusan kepolisian melakukan diversi.Melihat kebijakan yang diambil oleh pihak penyidik (Polres Batu), itu membawa dampak besar yaitu pelaku anak mendapat perlindungan extra. Dengan demikian penyelesaian yang melibatkan anak sebagai pelaku berpeluang besar untuk selesai pada tingkatan peyidikan dan pelaku anak dapat sejauh mungkin dijauhkan dari sistem peradilan pidana.

\section{Simpulan}

Berdasarkan hasil dalam pembahhasan yang telah diuraikan diatas, maka kesimpulan yang dapat dikemukakan guna menjawab rumusan masalah dalam penelitian ini adalah: 
1. Dasar pembentukan Pasal 9 ayat (2) Undang-UndangNo.11 tahun2012 tentang SPPA ialah: pertama,jikapersetujuan atau izin korban dan keluarga itu dicari, maka akan memperkecil peluang pelaku anak untuk memperoleh diversi. Kedua, sulitnya pencapaian diversi apabila harus meminta persetujuan korban dan akan terjadi diskriminasi terhadap ABH yang berasal dari keluarga kurang mampu. Ketiga, dalam Undang-Undang ini (UU SPPA) semangat kita bukan memenjarakan anak dalam proses pidana. Apabila harus meminta persetujuan korban, harus ada parameternya (angka kerugiannya). Keempat, pada proses diversi korban harus diberikan kesempatan untuk berpartisipasi. Apabila korban tidak ingin berpartisipasi, diversi tetap akan dijalankan.

2. Setelah melakukan perbandingan Proses diversi antara Indonesia dengan Negara Filiphina dan Malaysia, maka untuk mencapai bentuk ideal dalam proses diversi pada tindak pidana pencurian ringan yang dilakukan oleh anak di Indonesia ialah dengan melakukan sebuah kebijakan formulasi pada Pasal 9 ayat (2) Undang-Undang No. 11 tahun 2012 tentang SPPA menjadi:

"Untuk memperoleh kesepakatan pada proses diversi, diwajibkan untuk memperoleh persetujuan dari korban, terkecuali untuk tindak pidana yang berupa pelanggaran dan tindak pidana tanpa korban"

\section{DAFTAR PUSTAKA}

\section{Buku}

Adi Kusno, 2009, Diversi Sebagai Upaya Alternatif Penanggulangan Tindak Pidana Narkotika Oleh Anak, UMM Pres, Malang.

Barda Nawawi Arif, 1996, Kebijakan Legislatif dalam Penanggulangan kejahtan dengan Pidana Penjara, Universitas Diponegoro, Semarang.

Arif Barda Nawawi, 2008, Bunga Rampai Kebijakan Hukum Pidana, Kencana, Jakarta.
Romli Atmasasmita, 1992, Teori dan Kapita Selekta Kriminologi, Refika Aditama, Surabaya.

Maya Indah, 2014, Perlindungan Korban Suatu Perspektif Viktimologi dan Kriminologi, Kencana Prenadamedia Group, Jakarta.

Dikdik M Arif Mansur dan Gultom Elisatris, 2006, Urgensi Perlindungan Korban Kejahatan Antara Norma dan Realita, Rajawali Pers, Jakarta. 
Marlina, 2009, Peradilan Pidana Anak di Indonesia,Refika Aditama, Medan.

Philipus M. Hadjon, 1987, Perlindungan

Hukum Bagi Rakyat Indonesia, Bina Ilmu, Surabaya.

Abintoro Prakoso, 2013, Kriminilogi dan

Hukum Pidana, Laksbang Grafika, Jember.

Wagiati Soetedjo dan Melani, 2013, Hukum

Pidana Anak, Refika Aditama, Bandung.

Rena Yulia, 2009, Viktimologi Perlindungan

Hukum Terhadap Korban

Kejahatan, Graha Ilmu, Bandung.

Bambang Waluyo, 2011, Viktimologi

Perlindungan Korban dan Saksi,

Sinar Grafika, Jakarta.

\section{Naskah Internet}

Van der Schaar, Kemiskinan di Indonesia, http://indonesia-investments.com.

\section{Peraturan Perundang-undangan}

Undang-Undang Dasar Negara Republik Indonesia tahun 1945.

Undang-undang Nomor 1 Tahun 1946 tentang Kitab Undang-undang Hukum Pidana.

Undang-undang Nomor 8 Tahun 1981 tentang Kitab Undang-undang Hukum Acara Pidana.

Undang-undang Nomor 11 Tahun 2012 tentang Sistem Peradilan Pidana Anak.

Undang-undang No. 13 Tahun 2006 tentang Perlindungan Saksi dan Korban.

Undang-undang No. 39 Tahun 1999 tentang Hak Asasi Manusia.

Juvenile Justice and Welfare Act of 2006 (Republic Act No. 9344) Filiphina.

Child Act 2001 Malaysia.

Perma Nomor 2 tahun 2012 tentang Penyesuaian Batasan Tindak Pidana Ringan dan Jumlah Denda dalam KUHP 